\title{
Behind the Success of Online Petitions Movement of the MD3 Law Coalition in Indonesia
}

\author{
Hayuningtyas Aneswari Pujantoro \\ \{tyas.aneswari15@mhs.uinjkt.ac.id\} \\ Universitas Islam Negeri Syarif Hidayatullah Jakarta, Indonesia
}

\begin{abstract}
Today, a movement can be established within minutes through an online petition. One of the successful cases of this movement is the MD3 Law Coalition. In observing the phenomenon, several questions arose, what triggers the establishment of the MD3 Law online petition movement? How can a movement formed through online petitions managed to prevail in Indonesia? To answer the questions, this study uses the qualitative method and applies the Political Process Theory. The theory argues that there are three crucial components for the formation of a movement, i.e.: insurgent consciousness, organizational strength, and political opportunities. This study finds all of the components played important roles for the success of the Coalition. First, the movement is caused by the feeling of injustice from the House (insurgent consciousness). Second, the movement was led by prominent figures and established several online petitions (organizational strength). Third, Indonesia provides the political opportunities that the movement needs (political opportunities).
\end{abstract}

Keywords: Online Petition, Social Movement, Political Process Theory, The MD3 Law.

\section{Introduction}

In the modern era, a social movement is no longer limited to real space but also cyberspace. The emergence of the internet in the world of social movement has changed several aspects of people's involvement in the social and political sectors. Development of technologies have facilitated social movements significantly in terms of connecting with local and global networks, exchange ideas, produce and distribute news in relatively easier as well as cheaper compared to traditional communication models. This development has without a doubt, contributed to the success of social movements [1]. The success of a social movement requires synergy from all parties and the media. Take an example from the success of Katu's social movement in Sulawesi. It shows that besides being supported by the synergy of activists, the use of facilities and media also contribute positively to the success of social movements and networks builds [2].

The existence of technological developments, provides opportunities for political action to run easily, quickly, more universally. It can also form and disseminate news quickly [2]. The characteristics of virtual media which revolve around interactivity and networks can facilitate the development of social movements. One example of this media is the online petition. In the past, gathering people that care about a certain issue was difficult, required a lot of time, money and complex bureaucracy. However, nowadays, technology has made everyone more connected, can start a campaign and immediately mobilize hundreds of others locally or 
around the world, making governments and companies more responsive and accountable. Online petitions exist for a world where creating a change is a part of everyday life. Through online petitions, anyone who wants to make a change can collect signatures and opinions through digital social networks. For each support collected, the online petition site will send the petition to the email address of the party the petition is claiming. With an online petition, every individual can give birth to a social movement [2].

However, the power of those technologies should not be exaggerated. The internet alone cannot resolve all of life's problems [1]. Thus, online petitions could not be the sole contributor to the success of social movements. It requires other efforts such as 'offline movements' (e.g. protest and demonstration), media coverage, and meeting directly with policymakers that can increase the success of a petition [3]. Therefore, it can be concluded that though an online petition is only one of the significant factors of the success of social movements, it indeed plays an important role but needed to be combined with other factors. With the movement of against the revision of the MD3 Law in Indonesia as the case study and by applying political process theory (PPT), this article aims to illustrate how social movements through online petitions managed to be successful. PPT is considered suits the purpose of this study as it shows an understanding on how the Indonesian society fueled by grievances and a desire for change come together online to challenge the existing law, in this case the legalization of the revised MD3 Law. On the other hand, the theory also provides a framework for explaining how social movements formed through online petitions with other requisite factors can prevail. This article will first briefly explain the political process theory. Further, it will discuss how two components of political process theory, insurgent consciousness and organizational strength, resulted in motivating the emergence of the MD3 Law Movement and online petitions are used as the movement's organizational resource respectively. The discussion then moves to examine how political opportunities aspect of political process theory serves as the additional efforts needed by the movement to achieve the success of MD3 Law online petition movement.

From the explanation above, there are at least two main questions in regards to this phenomenon; what triggers the establishment of this online petition movement? How can a movement formed through online petitions managed to prevail in Indonesia?

\section{Research Method}

This research used the qualitative method. In general, qualitative research commonly uses a narrative research approach, phenomenology, grounded theory, ethnography, and case study. [4]. Descriptive research is research that explores and explains an individual, group, or event. The purpose is to describe the characteristics and functions. In other words, descriptive research defines aspects of a study, such as who, what, where, when, why, and sometimes how the research is [5]. This article will use the descriptive qualitative analytic method in executing question on how political process theory encourages the formation of the MD3 Law Coalition in Indonesia and why the online petition movement formed by the Coalition can be successful.

To answer the research questions, it uses the data collection technique. The method obtained data through literature reviews in the form of books, articles in journals, official reports, online news, and other data that can support this research. 


\section{Political Process Theory}

Social movements have been a media for civil society to voice opinions usually concerning their dissatisfaction for the performance of their government. The development of the theories of social movements started in the 1950s when an explosion of protests and demonstrations against governments, government policies, and existing social practices emerged in the US and Europe [6]. These movements include feminist and gender equality movement, the green or environmental movement, and so forth. The occurrence of these social movements arose the question as to why social movements are born and grow. Social scientists tried to develop theories to understand the origins of these movements as well as to predict the future course of these movements [6]. Some of the known social movements theories are as follows: deprivation (or relative deprivation) theory; resource mobilization theory; political process theory; structural strain theory; and new social movement theories $[6]$.

Political process theory, also known as political opportunity theory or political opportunity structure argues that a very important component for social movement development is political opportunities [7]. This theory looks at how the power of the government or state has affected the outcomes of social movements. Political process theory (PPT) assumes that if the government's position is inclined to oppressive behavior, there is a high chance that a social movement might fail. On the other hand, if the government is more tolerant to different opinions, then any social movement that is emerging has high opportunities to grow and flourish [6]. This argument is also supported by Foweraker (1995) when researching several social movements in Latin American countries. The research found that the outcome of social movements is highly tied to the nature of the political system that these movements have to contend with [6].

According to PPT, there are three crucial components for the formation of a movement, i.e.: insurgent consciousness, organizational strength, and political opportunities [7].

1. Insurgent Consciousness: an idea that certain members of society feel mistreated, deprived, have grievances or somehow perceive the system is unjust. The main focus of these conditions is on the external environments of social movements. People are motivated to organize a movement out of a collective sense of injustice brought forth by comparison to others or concerning their expectations [7].

2. Organizational Strength: is similar to the resource mobilization theory (RMT), it argues that a social movement must have a strong leadership and sufficient resource to be organized. The resemblance between this concept and the RMT is depicted on the mobilization of resources external to the movement. The associated organization also play an important role in recruiting as well as motivating people to join social movements. Often, the emergence of a movement merges with organized blocs of individuals which have previously been formed. Those preexisting blocs lend the movement resources and support.

3. Political Opportunities: A condition in which a political system is either receptive or vulnerable to a challenge. The vulnerability of a state creates an opportunity for the movement members to pull out their dissatisfaction and try to make a social change. This vulnerability can be the result of any of the following or a combination thereof:

- Escalation of political pluralism

- Decline in repression

- Elites disunity 
- Growth of institutional participation in the political process

- Support of organized opposition by elites

A main advantage of PPT is that it addresses why social movements emerge at a specific time. Though having grievances (insurgent consciousness) and resources to mobilization are important, if political opportunities are not available, social movements will not have any success. Only when all three of the above components are present, the movement has a chance to triumph [7].

\section{The MD3 Law and Online Petition}

The MD3 Law is a law on People's Consultative Assembly (MPR), People's Representative Council (DPR), Regional House of Representative (DPRD), and Regional Representative Board (DPD). This law contains rules regarding the authority, duties and membership of those state institutions. Rights, obligations, code of ethics and details of the execution of duties are also regulated. This rule supersedes Law Number 27 of 2009 concerning MD3 Law which is considered to be no longer following legal developments. This law consists of 428 articles, and was passed on August 5, 2014 by President Soesilo Bambang Yudhoyono. The latest revision was endorsed by the Parliament on Monday, February 12, 2018 [8]. The recent amendment of the law has at least four controversial articles, i.e. [9]:

- Article 73 on Forced Summoning of Citizens in which it states that the House of Representative has the authority to summon individual by force with the help of the National Police if that individual fails to present themselves after three summonses without a proper or legitimate reason.

- Article 122 on Contempt of Parliament states that the legislative body's ethics council (MKD) has the power to take legal actions against those that disrespect the dignity of the House and its members.

- Article 245 on House Immunity states that in any investigation concerning a member of the House, law enforcement authorities must acquire permission from the president and be reviewed by MKD.

- Article 15 and 84 on the Arrangement of People's Representative Council and People's Consultative Assembly Leadership in which these provisions added leadership positions at the House of Representative and the People's Consultative Assembly.

Each amendment has critics stated by various parties. Article 73 on Forced Summoning of Citizens, for instance, has been criticized by FKHK stating that the House works to form the law and supervise its enforcement, not taking legal steps. Moreover, the forced summoning is an instrument in which should be used to control those in power, not the public's behavior [9]. Other critics can be found on Article 245 on House Immunity and Article 15 and 84. In Article 245 , a human rights group, Setara Institute argued the article can be interpreted as giving "absolute immunity" to the House members, which means they are free from being prosecuted in any criminal offence. The critic for Article 15 and 84 came from PPP chairman Romahurmuziy who said the additional positions at People's Consultative Council are a waste of the state's budget and could potentially lead to an abuse of power [9].

The critics for the amended MD3 Law show the dissatisfaction for the injustice behaviour conducted by the House. Correspond with the Insurgent Consciousness aspect, people are motivated to organize out of a sense of deprivation or inequality brought forth by comparison 
to others, or concerning their expectations. In this case, people will join social movements because their expectations will have outgrown their actual situation [10]. In the MD3 Law case, the public felt betrayed by the amendments of the Law which seemingly favour those in power, not the public. Society perceived this as injustice, which produces social frustration. The public thus wishes for a better situation as well as beneficial for various parties [11]. This, therefore, become the cause for the public to conduct various protests and demonstrations both offline and online.

In spite of that, insurgent consciousness cannot be the sole reason a movement is able to be successful. Grievances alone or even rational thought are not enough to bring people to act collectively [10]. Thus, the organizational strength component of political process theory plays the role to enhance the chance of bringing the citizen together to form a movement. The component focuses on the leadership and sufficient resource of the organization or movement. This component recognizes a social movement's ability to use organization and other resources to promote social change. The online petitions are one of the resources to bring people into collective action, in this case, against the amendment of the MD3 Law. The online petition site which was used to gather voices to reject the MD3 Law was Change.org. This site provides services to make it easier to create a petition, disseminate it, and strengthen group networks directly, and also practically targeting governments at all levels, companies, and other groups that are under public scrutiny [12]. Change.org also utilizes Social Networking Site (SNS) such as Facebook, Twitter and also content sharing sites like Youtube to support the petition function. According to Henriques (2011) in Lizarraga, et al. (2016) the power of internet especially in terms of SNS use, can change the form of communication and organization as well as find a new form of social participation [12]. The Change.org Indonesia Manager facilitates the initiators of the petition to connect with the media, the community and policymakers to achieve the goals of policy change. The site actively advocates for media through press conferences, sending press releases and press notes through emails to journalists, partnering with media companies, promoting petitions through social media. These efforts have received positive responses from the media and the issues that the petition has made are usually being reported by the media. Digital media especially are considered the most responsive as they can produce news in a relatively fast time [3]. Based on Arief Aziz's information, the mass media and online media have a fairly high interest in raising the issues that are reflected. The statement shows that the use of Change.org Indonesia's online petition platform has the potential to attract media attention and generate news [3]. This is done to make the issue become public discussion, thus attracting the attention of policymakers.

Efforts to encourage the media to cover certain issues can also be done by escalating petition issues through other online activism, for example through social media and offline actions such as protests or taking to the streets to attract media attention. Petitioners must actively garner support through social media and build public conversations about social issues or problems that are pioneered and invite the media to participate in distributing petitions to the public at large [3]. The use of social media to promote petitions and policy changes can increase opportunities for media coverage. This is supported by the fact that the mainstream mass media now also use social media as a news source. Many media professionals and journalists accept the social media platform as a source of electronic information as it is rich in information for journalists and has been proven to have a major impact on news reporting [3]. Social media and social networking change the way news are generated and accessed and the platform influences media in three dimensions including as a tool for journalists to create content, as a tool for distributing information, and as a tool for finding, receiving, and accessing information [3]. Not only to promote petitions, but social 
media can also be used by petition initiators to directly connect with policy makers through policy makers' social media accounts [3].

To make a successful movement, it takes more effort than just making an online petition. Movement outside the internet, can be started from attracting media attention to the petition that has been made, making protest movement, and communicate as well as negotiate with decision makers. Destrity (2014) explains that efforts to propose policy changes through the online platform Change.org Indonesia petition are often supported by other activities in order to attract the attention of the public and policy makers. These activities include offline protests or taking to the streets, efforts to educate the public on related issues, media advocacy through press conferences and sending press releases to journalists' networks, building coalitions with communities, and lobbying with related parties [3]. One of the offline movement efforts but still using online petition to support it was done by Hendrik Rosdinar, the coordinator of the MD3 Coalition. He stated that the law must be sued completely, both material and formal. To strengthen the formal test in the Constitutional Court, Hendrik plans to attach the online petitions signed by around 205,000 citizens who reject the MD3 Law. Other actions that have been taken by the public to thwart the legalization of the MD3 Law was done by direct protest and demonstrating. Several demonstrations by students were seen in many areas [13]. In Medan, students uprooted the gate of the Regional House of Representative (DPRD) office. Then four students in Bengkulu were arrested by the police on March 5 as the demonstration led to chaos. Students in Surabaya blocked the road in front of the DPRD when they refused to revise the MD3 Law at the end of February [8].

The organizational strength component does not only focus on resources to run the movement, but also leadership. Though each petition that against the MD3 Law was not initiated by one initiator, each of them which has different pioneers are able to lead the public and the media to sign the petition as well as be covered on the news media. This happened due to the petitions were initiated by various parties who were previously known to be active in voicing public justice. For instance, the online petition named "Rejecting the revision of the MD3 Law, the DPR cannot prosecute criticism!" signed by 203 thousand supporters [14] was initiated by several civic non-governmental organizations, such as the Legislative Monitoring Committee (KOPEL), the Indonesia Corruption Watch (ICW), the Association for Elections and Democracy (Perludem) and the Indonesian Center of Law and Policy Studies (PSHK) or better known as the MD3 Law Coalition [14]. Another petition which denied the MD3 Law was initiated by the Legal and Constitutional Review Forum (FKHK) and the Indonesian Solidarity Party (PSI). The petition that initiated by PSI got covered in one of the online media, BBC.com. The news reported one of PSI Chairwoman Grace Natallie's claimant, in which she stated that the petition which filed by her party was based on the public's demand. This media coverage combined with petitions initiated by several prestigious pioneers, make the previously controversial amended law becomes a more discussed issue by the public. Thus, attracting the public to sign the petitions.

In brief, an online petition, media coverage, direct protest and demonstration, as well as social media would, therefore, be categorized as organizational resources for the movement. These resources can be used to mobilize the group due to the large network reach that it potentially can command [15]. On the other hand, though the movement through online petition has no definitive leadership like the common social movement, the initiators of the petitions act as if the leaders. These petitioners, through media, influence the public to support the petition. This, combined with the organizational resources, resulted in organizational strength for the MD3 Law movement.

The indicator of the successful use of online petition in influencing policies is not based 
on the supporter numbers of the petitions. Got covered by the media, the increase of public awareness and support from the public both online and offline can be considered far more important than the number of the supporter of the petition. The large numbers of people who signed the petition do not determine the success of it, however, it at least contributes to increasing the chances of the petition to be triumphant. The greater the number of supporters may result in the dissemination of the petition through social media, which eventually led to media coverage, therefore attracting the policymakers [3].

\section{Political Opportunities and the Success of MD3 Law Online Petition- Based Movement}

Attracting the policymakers and the public on the issue an online petition is claiming is not adequate according to the political process theory. This theory pays another great concern on political opportunities aspect as one of the factors why a social movement succeed. Political opportunities component explains the state's condition affects the success of the movement. If the states are vulnerable to change, then the movement has a high chance of triumph. The vulnerable situation of a state is influenced by at least five factors, i.e.: escalation of political pluralism, the decline in repression, elites disunity, growth of institutional participation, and elites' support to organized opposition. The escalation of political pluralism exists in Indonesia. The state is very plural in terms of political parties and non-partisan individuals. In 1999, a total of 48 political parties advanced to the election. It is considered a big leap for Indonesia to have 48 political parties from previously only three parties [16].

According to Ronald H Chilcote (political comparison expert), that in political pluralism, the value of democracy is based on the diversity of interests and the spread of power. Political pluralism is a democratic space that is able to open up blockages so that power from various groups of people can flow freely towards people's control of the state. Democracy has guaranteed that political pluralism in a country will not give birth to a totalitarian state, it will not create centers of power in certain groups (such as in the old and new order of Indonesia). There should be no intention whatsoever of the actions of certain groups of people to dominate other groups of people in a system of state power, both state power at the national level (central government) or state power in the region (local government). In the dimension of political pluralism, all people through various "entities" channels and their communities must be given a way to control power or influence power. Through this way the people can send people who have been chosen to enter the legislative and executive bodies [17].

Today, Indonesia has given its people the right to be able to enter into government institutions both through political parties and non-political parties. Besides political parties, non-political people can enter parliament as members of the DPD RI, and non-political people can also become governors, regents / mayors through independent channels. Both groups of people have been given the same right by the state to enter the power system [17].

The decline in repression can be seen through the democratic system in Indonesia. The Ambassador of the Republic of Indonesia for Great Britain, concurrently Ireland and the International Maritime Organization (IMO), Rizal Sukma, stated that Indonesia is a country with the best democracy progress in the region. Sukma further described several achievements of Indonesian democracy, namely freedom of the press and a civil-based government system, a decentralized system. Freedom of the press is one of the first and foremost achievements of Indonesia's democracy. At present, the Indonesian press has become more dynamic and open. 
Sukma explained that criticism in foreign media seems lighter, while local media are more critical. However, according Anton Alifandi from the Financial Times Confidential Research, there is a tendency of media ownership by certain political groups. This is then often used for certain political purposes. The second achievement according to Sukma was the change in the system of government that had been dominated by military power, to become a civil-based government. Whereas the decentralized government system becomes the third achievement of Indonesian democracy [16].

Other factors that affected the success of against of the MD3 Law online petition movement, aside from the escalation of political pluralism and the decline in repression in Indonesia, is the elite disunity. This is shown through parties that supported the legalization of the MD3 Law amendment. Eight parties consisted of the Indonesian Democratic Party of Struggle (PDI-P), Golkar Party and the Democratic Party bolstered the Law while two, the United Development Party (PPP) and the National Democratic Party (Nasdem), opposed to it [9]. The parties which are combined in the House as the initiators of the MD3 Law are instead fragmented internally. Furthermore, the Solidarity Party (PSI) supported the public's movement through making a petition against the MD3 Law and wish judicial review conducted in the Constitutional Court. Thus, creating sides within the Indonesian political elites in regard to the case [16]. FKHK, PSI, KOPEL, ICW, Perludem, PSHK, and academicians which opposed the law, are not only the "leaders" of the MD3 Law movement. The organizations have also established the idea of the public who opposed the law received supports from the elites as well as the broadening of institutional participation in the political process in Indonesia. It proves that they are not afraid to voice out their disagreement against the House, and no institution or person should ever will.

President Jokowi's action on refusing to sign the revision of the MD3 law can be seen as a "support from elite figures:" factor. However, Jokowi's refusal to sign the revision was considered ambiguous to some political studies experts as each law in Indonesia should have been made by the People's Representative Council and the President. Thus, it can also be said, there is a possibility that Jokowi agreed to this law. Therefore, Jokowi's action cannot yet be considered to be a component of "support from elite figures" which is one of the factors why a social movement succeed.

\section{Conclusion}

A social movement is no longer limited to direct protest and demonstration. Technology has contributed to the advanced form of a social movement. This latest form of movement is often called as the New Media. One of its examples is the emersion of the online petition. The petition offers opportunities for people to gather supports within minutes and start a change. However, a social change cannot occur with just a click on the online petition. Social transformation needs other factors. The political process theory (PPT) exists to examine the motive, the resource, and the factor of the emergence and the success of a social movement. With PPT, it is known that the emergence of the MD3 Law movement was caused by feelings of unfairness created by the House. However, grievances alone cannot produce collective action nor is the sole factor of the successful of the movement. The organizational strength which includes leadership and organizational resources aspects become the platform of the movement to occur. With online petitions and SNS as their resources as well as prominent petition initiators as their leaders, the movement attracts even more people to sign the petition 
also policymakers to cancel the legalization of the law.

Nevertheless, political opportunities are also necessary to achieve a successful movement. The concept describes the vulnerability and receptivity of a state to challenge. The vulnerability can be influenced by five factors: the growth of political pluralism; decline in repression; elite disunity; a broadening of access to institutional participation in political processes; and support of organized opposition by elites. In the MD3 Law case, Indonesia includes all of the factors moderately. The political pluralism can be seen through the increasing political parties and non-parties' participation in the political system of the state. Although freedom of the press has been ensured, there is an inclination that it is being used by certain groups for certain political purposes. Moreover, the division with elites, in this case, the parties in the House also occurred. The factions are divided into two sides, the ones who are in favor and decline the law. Parties who refused the law held a walk-out of the House office and one of the opposing them established the MD3 Law online petition movement. The opposing party alongside other institutions and academicians spread their refusal to the law through online petitions, SNS, even request judicial review to the Constitutional Court. The movement done by political parties, related institutions, and academicians is the image of an escalation of institutional participation in the political process. In short, the MD3 Law movement is caused by the injustice that the House produced, the movement led by prominent figures consisted of political parties, institutions, and academicians then establish several online petitions to show their refusal, spread them through SNS, become media coverage, held demonstrations, and demand for judicial review to the Constitutional Court. The Court itself considered the law to be not in accordance with the functions of the People's Representative Council. Moreover, the law has indirectly given the unlimited immunity to the House member. Thus, the Court decided to thwart the legalization of the law. The movement's actions combined with political opportunities that Indonesia has, resulted in the triumphant of the movement. The MD3 Law Coalition then proved the crucial three components of political process theory to be important for a social movement to be successful.

\section{References}

[1] H. Molaei, "Discursive Opportunity Structure and the Contribution of Social Media to the Success of Social Movements in Indonesia," Information, Commun. Soc., vol. 8, no. 1, pp. 94-108, 2015.

[2] D. R. Hapsari, Peran Media Baru dalam Perkembangan Gerakan Sosial. Bogor: Institut Pertanian Bogor, 2012.

[3] N. A. Destrity, "Petisi Online sebagai Media Advokasi Alternatif dalam Upstream Social Marketing," J. Komun. Glob., vol. 7, no. 2, 2018.

[4] J. W. Creswell, Research Design: Qualitative, Quantitative, and Mixed Methods Approaches. Thousand Oaks: Sage Publications, 2003.

[5] "Chapter 3: Research Methodology of A Study of Buying Decision Process in Malls." [Online]. Available: http://shodhganga.inflibnet.ac.in/bitstream/10603/97412/5/chapter 3.pdf.

[6] A. Sen and O. Avci, Why Social Movements Occur: Theories of Social Movements. Bilgi Ekonomisi ve Yönetimi Dergisi, 2016.

[7] R. R. T. Cragun et al., Introduction to Sociology Course Textbook. The University of Tampa Sociology Department, 2014.

[8] "Tujuh Hal yang Harus Diketahui Soal Revisi UU MD3," 2018. [Online]. Available: https://www.bbc.com/indonesia/trensosial-43397697. [Accessed: 18-Aug-2019].

[9] Sheany, "Reviewing the Controversial MD3 Law," Jakarta Globe, 2018. [Online]. Available: https://jakartaglobe.id/context/reviewing-controversial-md3-law-prevent-people-freedom/. [Accessed: 16-Aug-2019].

[10] A. R. Lopes, The Impact of Social Media on Social Movements: The New Opportunity and 
Mobilizing Structure. Creighton University, 2014.

[11] M. Dedy, "Pengorganisasian Gerakan Sosial Berbasis Petisi Online (Studi Kasus: Change.org Indonesian Chapter)," Inf. Kaji. Ilmu Komun., vol. 47, no. 1, 2017.

[12] Ayu A.K, Penggunaan Petisi Online Change.org dalam Penyebaran Isu dan Melawan Diskriminasi Sosial di Indonesia. Jakarta: Universitas Terbuka, 2016.

[13] A. Utama, "UU MD3 Digugat dari Berbagai Sisi: Petisi hingga Formil-Materiil," BBC Indonesia, 2018. [Online]. Available: https://www.bbc.com/indonesia/43412267. [Accessed: 18-Aug-2019].

[14] “Tolak Revisi UU MD3, DPR Tidak Boleh Mempidanakan Kritik," Change.org, 2018. [Online]. Available: https://www.change.org/p/tolak-revisi-uu-md3-dpr-ri-tidak-boleh-mempidanakan-kritik. [Accessed: 16-Aug-2019].

[15] S. M. Tham, Social Media as a Resource in Social Movements: An Online Resource: Mobilization Study of the Formation of Social Movement Organizations. Michigan State University, 2016.

[16] E. Damhuri, "Bisakah Demokrasi dan Pluralisme Berjalan Beriringan," Republika.co.id, 2017. [Online]. Available: https://www.republika.co.id/berita/nasional/umum/17/11/24/ozwcrv440bisakah-demokrasi-dan-pluralisme-berjalan-beriringan. [Accessed: 25-Aug-2019].

[17] Z. A. Tabrani, "Demokrasi dan Pluralisme Politik, Universitas Islam Indonesia," 2015. [Online]. Available: https://master.islamic.uii.ac.id/article/demokrasi-dan-pluralisme-politik/. [Accessed: 28Aug-2019]. 